\title{
Ancient Scholars on the Horoscope of Rome
}

\section{Stephan Heilen}

\begin{abstract}
This contribution analyses the preserved reports on the only attested case in which Greco-Roman scholars practiced technical chronology in combination with astrological history, a branch of celestial divination that was to be developed systematically only later by Persian and Arabic scholars. Passages from Cicero, Plutarch, Solinus and John Lydus allow us to reconstruct how Lucius Tarutius of Firmum, a Roman expert in astral sciences, calculated, at the request of the antiquarian Varro, the exact dates of the conception and birth of Romulus as well as that of the foundation of Rome. Particular emphasis is given to the question of why Tarutius departed from the traditional foundation date in April 753 BCE in favor of an earlier date in October 754 BCE. It is also argued that Lucan's famous speech of Nigidius Figulus (Lucan. 1.639-672) may well contain a hitherto overlooked intertextual allusion to Tarutius' horoscope of Rome.
\end{abstract}

In the $16^{\text {th }}$ century European scholars first recognized and pointed out the difference between two auxiliary disciplines of historiography that had long been practised together: technical chronology and astrological history. ${ }^{1}$ Technical chronology uses ancient reports of eclipses of the sun and moon to determine absolute dates of ancient historical events. It is still today the central pillar on which our chronology of the Greco-Roman world and the ancient Near East is based. Astrological history is equally based on the movements of the heavenly bodies, but - unlike technical chronology - it assumes that these movements have an influence on human history. Astrological history was systematically developed by Persian and Arabic scholars and enjoyed a large reception in the Latin

\footnotetext{
${ }^{1}$ See Anthony T. Grafton and Noel M. Swerdlow, 'Technical Chronology and Astrological History in Varro, Censorinus and Others', Classical Quarterly n.s. (1985) [hereafter Grafton - Swerdlow, 'Chronology'], vol. 35, pp. 454-65; and by the same authors: 'The Horoscope of the Foundation of Rome', Classical Philology (1986) [hereafter Grafton - Swerdlow, 'Horoscope'], vol. 81, pp. 14853.
}

Stephan Heilen, 'Ancient Scholars on the Horoscope of Rome', Culture And Cosmos, Vol. 11 no 1 and 2, Spring/Summer and Autumn/Winter 2007 pp. 4368.

www.CultureAndCosmos.com 
West until the end of the Renaissance. It claims to be able to predict historical events and the life-span of entire states. The present contribution is devoted to the earliest attested case in which technical chronology and astrological history were practised together. The preserved sources allow us to reconstruct an interesting research project of the period of the late Roman republic.

Among Roman scholars of the middle of the first century BCE, there was an increasing interest in time reckoning and chronology. While Julius Caesar had the Roman calendar reformed (45 BCE), scholars like Varro, Atticus and others tried to establish a reliable chronology of the Roman past. The most important date to investigate was that of the foundation of Rome. According to tradition, Rome had been founded on the pastoral feast of the Parilia on the $21^{\text {st }}$ of April. But the sources disagreed on the year of the foundation. Eventually Varro adopted the calculation of Atticus who had dated the foundation of Rome to 753 BCE. The method for obtaining this date was twofold: first, one had to count backwards to the foundation of the republic by reckoning all the years of the Roman magistracies as recorded in various sources. This leads to 509 BCE. Second, one had to add the traditional number of 244 years for the period of the Roman kings. This leads to 753. The $21^{\text {st }}$ of April of this year is, technically speaking, the epoch of the Varronian era $a b$ urbe condita.

Now Varro tried to take a third step backwards. For him, Romulus was a historical figure, and we know from Censorinus ${ }^{2}$ that Varro drew the dividing line between mythical and historical time in the summer of 776 BCE with the introduction of the Olympiad Reckoning. According to tradition, Romulus was around 18 years of age when he founded Rome. The addition of 753 plus 18 leads us back to April 771 BCE, plus/minus a few months. Varro aimed at determining, within this range of uncertainty, the precise birthday of Romulus which he probably considered to be the very origin of Roman history.

To this purpose, Varro asked the help of a certain Tarutius of Firmum. From Pliny the Elder we know that Tarutius wrote in Greek about the stars. ${ }^{3}$ To this authority on astronomical questions Varro put the challenging problem of reconstructing, by astrological means, the planetary alignment under which Romulus had been born. As we shall see, Tarutius not only resolved this problem, but provided Varro with three distinct

${ }^{2}$ Cens. 21.1. All abbreviations of Latin authors follow the Index (1990) of the Thesaurus Linguae Latinae.

${ }^{3}$ Plin. nat. 1.18 ind. auct. 
horoscopes: that of the conception of Romulus, that of the birth of Romulus, and that of the foundation of Rome. ${ }^{4}$

Swerdlow has proved ${ }^{5}$ that Tarutius computed the planetary alignment of more than 700 years before his own time quite accurately and that he eventually discarded the traditional date of the foundation of Rome in the spring in favour of an earlier date in the previous autumn. Grafton and Swerdlow affirm that Tarutius must have had some astrological motive for refusing the traditional date, but they leave open what exactly this motive might have been. I shall try to provide an answer to this question and to show that Tarutius' astrological reasoning has left traces not only in the poem of Manilius, which has long been recognized, but also in the Pharsalia of Lucan.

Our earliest source on Tarutius is Cicero. In his treatise on divination (44 BCE) he adduces several sceptical arguments against the validity of astrology, mostly derived from Panaetius. Among other things, he criticizes the practice of casting horoscopes not only of human beings but also of animals and cities. In this context he says (Cic. div. 2.98): ${ }^{6}$

Lucius quidem Tarutius Firmanus familiaris noster in primis Chaldaeicis rationibus eruditus urbis etiam nostrae natalem diem repetebat ab iis Parilibus, quibus eam a Romulo conditam accepimus, Romamque, in iugo cum esset luna, natam esse dicebat nec eius fata canere dubitabat.

Our friend Lucius Tarutius of Firmum, who is particularly learned in Chaldaic calculations, tried even to derive our city's birthday from that feast of Pales on which tradition says it was founded by Romulus, and he said

\footnotetext{
4 I am not convinced by the arguments of Patrizio Domenicucci, Astra Caesarum. Astronomia, astrologia e catasterismo da Cesare a Domiziano (Testi e studi di cultura classica, vol. 16, Pisa, 1996) [hereafter Domenicucci, Astra], pp. 126-33, who tends to believe that - against the explicit testimony of Plut. Rom. 12.3-6 - only the horoscope of Rome had been cast by Tarutius around 45 $\mathrm{BCE}$, and that the two horoscopes of Romulus are later supplements made by Tarutius or someone else in order to establish astrologically flattering relations between Augustus and Romulus.
}

5 In Grafton - Swerdlow, 'Chronology', pp. 458-459; see also Grafton Swerdlow, 'Horoscope', p. 151.

${ }^{6}$ M. Tulli Ciceronis [...] De divinatione [...], ed. W. Ax (Leipzig, 1938). 
46 Ancient Scholars on the Horoscope of Rome

that Rome was born when the moon was in the sign of the yoke $[=L i b r a]$ and did not hesitate to predict her destiny.

Cicero mentions only the foundation of Rome, not the conception and/or the birth of Romulus. The only heavenly body that Cicero mentions is the moon (in Libra). In ancient astrology the allegedly humid, waxing and waning moon symbolizes biological growth.

Next comes Plutarch (c. 100 CE). In his Life of Romulus, he gives a more detailed account than Cicero. Plutarch says (Plut. Rom. 12.3-6): ${ }^{7}$

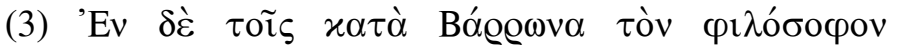

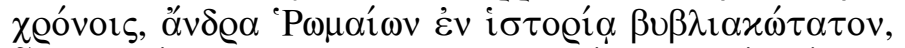

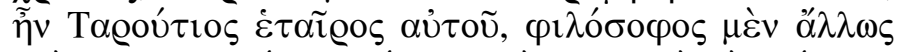

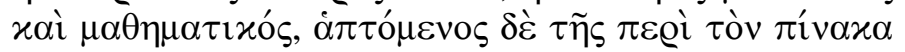

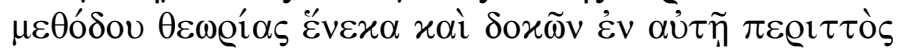

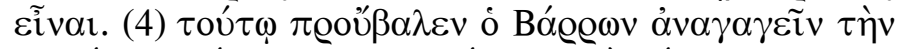

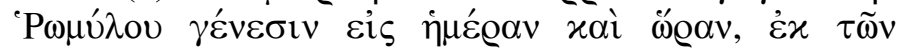

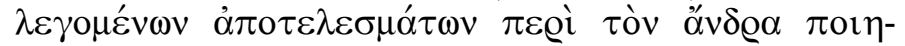

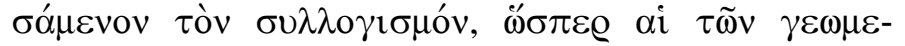

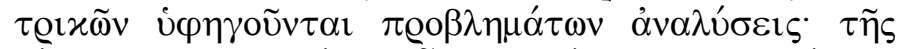

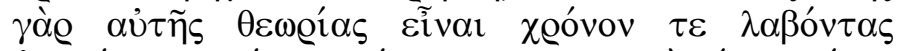

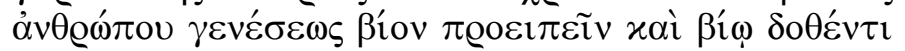

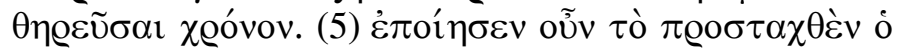

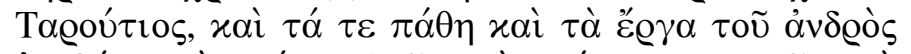

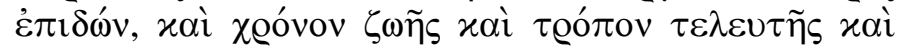

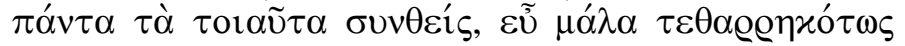

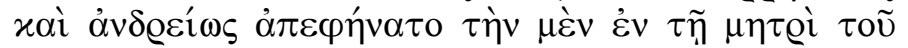

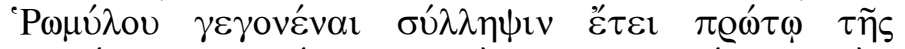

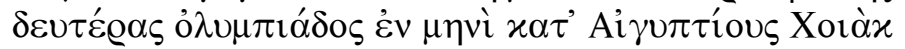

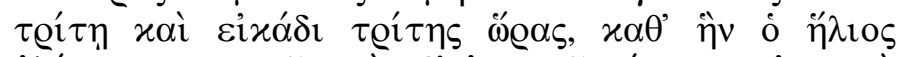

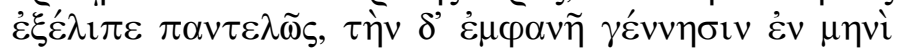

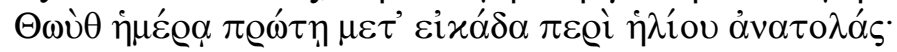

${ }^{7}$ Plutarco. Le vite di Teseo e di Romolo, eds Carmine Ampolo and Mario Manfredini (Milan, 1988) [hereafter Ampolo - Manfredini, Plutarco]. My English translation partly follows that of Bernadotte Perrin in Plutarch, Lives [...] with an Engl. transl., vol. 1 (Loeb Classical Library, vol. 46, Cambridge, MA/London, 1914; many repr.), pp. 121-123. All abbreviations of Greek authors follow the style of H. G. Liddell, R. Scott and H. S. Jones, A Greek-English Lexicon $\left(9^{\text {th }}\right.$ ed., Oxford, 1996). 


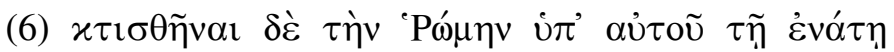

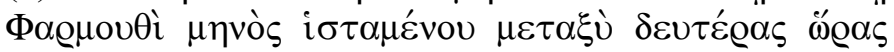

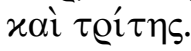

(3) In the times of Varro the philosopher, a Roman who was most deeply versed in history, there lived Tarutius, a companion of his, who, besides being a philosopher and an astronomer, had applied himself to the procedure that is based on the 'pinax' because of theoretical interest and was thought to excel in it. (4) To this man Varro gave the problem of fixing the day and hour of the birth of Romulus, making from the so-called effects his deductions concerning the man, just as the solutions of geometrical problems are derived; because, he said, it is theoretically the same to take the time of a man's birth and to foretell his life or to hunt out, from the given (facts of his) life, the time (of his birth). (5) This task, then, Tarutius performed, and when he had taken a survey of the man's experiences and achievements, and had brought together the time of his life, the manner of his death, and all such details, he very courageously and bravely declared that the conception of Romulus in his mother's womb had occurred in the first year of the second Olympiad [= 772/1 BCE], in the month Choiak of the Egyptian calendar, on the twenty-third day $[=24$ June $772 B C E]$ in the third hour $[=c .6: 54-8: 10 A M]$, when the sun was totally eclipsed; and that he was born in the month Thoth, on the twenty-first day [= 24 March <771> $B C E]$, at sunrise; (6) and that Rome was founded by him on the ninth of Pharmuthi $[=4$ October $<754>B C E$ ] between the second and third hour $[=c .7 .55-8.54 \mathrm{AM}]$.

As to the term 'pinax' (12.3), translators either resort to vague renderings or take it to mean an astronomical table with planetary positions. The latter one is, indeed, a meaning that 'pinax' has in certain other contexts. Here, however, it means the board which ancient astrologers used to illustrate planetary alignments during consultations with their clients. Plutarch did not write for professional astronomers but for a large public 
48 Ancient Scholars on the Horoscope of Rome

interested in biographies and entertainment. ${ }^{8}$ This public - like Plutarch himself - is not likely to have been familiar with planetary tables, but we may safely assume that it had either heard of or personally seen the circular zodiacal board, the main equipment of practicing astrologers which was widespread in the Greco-Roman world. ${ }^{9}$ The most famous such 'pinax' is described in the novel of Pseudo-Callisthenes on Alexander the Great where Nectanebo shows Olympias the state of the heavens on a precious horoscopic board, urging her to endure her labour a little longer until the moment is suited to give birth to a world ruler. ${ }^{10}$ As to the archaeological evidence, the best example is the board found by Daressy (Figure 1). Planetary markers of various colours used to be put on the various sections of the board which symbolize the twelve zodiacal signs. In the papyri, similar diagrams illustrate horoscopes. ${ }^{11}$ They are the origin of the diagrams used in modern astrology.

\footnotetext{
${ }^{8}$ See Plut. Rom. 12.6 (the continuation of the above quoted text): $\dot{\alpha} \lambda \lambda \dot{\alpha} \tau \alpha \tilde{v} \tau \alpha$

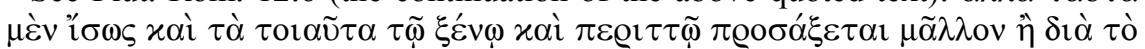

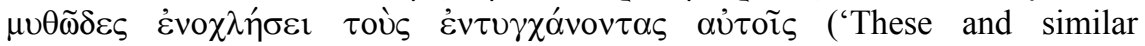
speculations will perhaps attract readers by their novelty and extravagance, rather than offend them by their fabulous character.')

${ }^{9}$ Two of these boards of Egyptian origin have been found at Grand in northern France where they had been thrown into a well in late antiquity. See Les tablettes astrologiques de Grand (Vosges) et l'astrologie en Gaule Romaine. Actes de la Table-Ronde du 18 mars 1992 organisée au Centre d'Études Romaines et GalloRomaines de l'Université Lyon III, ed. Josèphe-Henriette Abry (Lyon, 1993). See also James Evans, 'The Astrologer's Apparatus: A Picture of Professional Practice in Greco-Roman Egypt', Journal for the History of Astronomy (2004), vol. 35, pp. 1-44, which discusses extant pinakes and other tools of the ancient astrologer.

${ }^{10}$ See Ps.-Call. Hist. Alex. Magn. 1.4.5 in: Historia Alexandri Magni (PseudoCallisthenes), vol. I: Recensio vetusta, ed. G. Kroll (Berlin, 1926, repr. 1958). For an English translation, see The Greek Alexander Romance, translated with an introduction and notes by Richard Stoneman (London et al., 1991).

${ }^{11}$ See, for instance, the diagram of P. Oxy. II 235 in Otto Neugebauer and H. B. van Hoesen, Greek Horoscopes (Memoirs of the American Philosophical Society, vol. 48, Philadelphia, 1959; repr. 1987), pp. 18-19, no. 15/22.
} 


\section{Figure 1. The Daressy Table (from Roman Egypt, 25 cm diameter)}

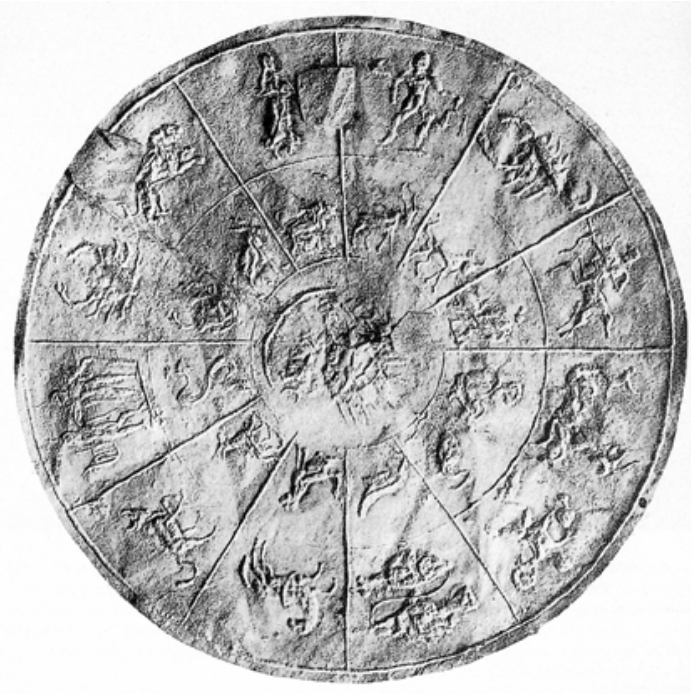

According to Plutarch, Varro's leading idea was to determine the day and hour of Romulus' birth by reversing the usual astrological procedure. Usually the astrologer starts his analysis from a given time of birth, determines the planetary alignment of that moment, and moves on to make inferences on the future life of the newly born individual. Varro, instead, already knows the life and deeds of Romulus. He wishes to make inferences from these events - in his view: stellar influences - backwards to the cause, that is: to the planetary alignment at the birth of Romulus. Once that alignment has been found, one can determine its calendrical date. An ancient scholion explains Varro's methodological comparison with geometry in the sense that one can equally calculate the plane measure of a square from its side and vice versa. Yet this is not what Varro meant: in ancient geometry, 'analysis' was a particular kind of mathematical argument based on a reversal of the normal 'synthetic' method of proof, and 'analysis' could be applied to either 'theorems' or 'problems' (Varro was thinking of the latter). ${ }^{12}$ Varro's comparison is not

12 See Pappus of Alexandria. Book 7 of the Collection, ed. Alexander Jones (New York et al., 1986), pp. 66-68 (introd.); 82-84 (Papp. 7.1-2); 380-381 (comm.). I am grateful to A. Jones for explaining Varro's intention to me. 
surprising since he devoted an entire book of his lost Disciplinae to each one of these liberal arts, one to geometria and another one to astrologia. ${ }^{13}$

The term $\gamma^{\prime} \varepsilon \varepsilon \varepsilon \sigma \iota \varsigma$ (12.4) is the key to understanding why Tarutius calculated not only the birth but even the conception of Romulus. It literally means 'origin'. Ptolemy and other astrologers discussed the modern-looking question of when exactly human life begins, at conception or birth. They decided that conception is the true beginning of life, and that a horoscope should be cast for this very moment. The moment of birth was considered to be secondary in importance and to be used only as a substitute when, as is normally the case, the precise time of

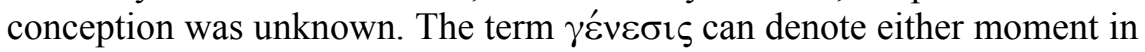
astrological theory. If needed, a differentiation was made, as here in Plut.

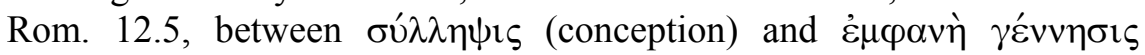
(visible birth).

The dates calculated by Tarutius do not, as some scholars assume, refer to the Alexandrian calendar. ${ }^{14}$ It was only some two decades after Varro's consultation with Tarutius that the Emperor Augustus firmly established the Alexandrian calendar in Egypt and brought it into a fixed relation with the new Julian calendar. Tarutius used the old Egyptian calendar, the so-called annus vagus. This is the only ancient calendar without any irregularities. It was therefore preferred by ancient astronomers and astrologers, even in late antiquity.

\footnotetext{
${ }^{13}$ In the primary sense of what we call 'astronomy'. The modern (allegedly enlightened) distinction between the 'science' of astronomy and the 'superstition' of astrology was unknown in antiquity. Both terms astronomia and astrologia could be used to denote either one. See Wolfgang Hübner, Die Begriffe 'Astrologie' und 'Astronomie' in der Antike. Wortgeschichte und Wissenschaftssystematik mit einer Hypothese zum Terminus 'Quadrivium' (Wiesbaden, 1989).

${ }^{14}$ This interpretation goes back to the late $19^{\text {th }}$ century and has been adopted (without knowledge of Grafton - Swerdlow, 'Chronology' and 'Horoscope') by Josèphe-Henriette Abry, 'Auguste: la Balance et le Capricorne', Revue des Études latines (1988), vol. 66, pp. 103-121, here p. 109; repeated (this time with knowledge of Grafton - Swerdlow, 'Chronology' and 'Horoscope') in: J.-H. Abry, 'L'horoscope de Rome (Cicéron, Div., II, 98-99)', in Les astres. Actes du colloque international de Montpellier 23-25 mars 1995, eds B. Bakhouche, A. Moreau and J.-C. Turpin, vol. II (Montpellier, 1996) [hereafter Abry, 'L'horoscope'], pp. 121-140, here p. 127, n. 15. The assumption that the dates refer to the Alexandrian calendar is furthermore of central importance to the speculations of Domenicucci, Astra.
} 
It is now time to reconstruct what Tarutius did. There was Varro's premise that the date of Romulus' birth had to be found 18 years before the Parilia of $753 \mathrm{BCE}$, which leads to the spring of 771 BCE. Consequently, the conception date had to found in the summer of the preceding year, $772 \mathrm{BCE}$. A little more than one hour after the day and hour given by Tarutius, there actually was an ecliptic conjunction, which is the condicio sine qua non for a solar eclipse. Modern computation reveals, however, that all that occurred was 'a barely grazing eclipse of the sun that could be seen, if at all, only in far northern latitudes'. ${ }^{15}$ Apparently Tarutius had a means of calculating over large intervals the dates of ecliptic syzygies, maybe by counting backwards from a recorded and dated solar eclipse, in units of one Saros cycle each. But Tarutius must have been unable to determine the lunar parallax, which determines whether or not an eclipse occurs at the time when both luminaries are on the longitude of either the ascending or the descending node.

The astrological reasoning of Tarutius is clear. Solar eclipses are the most impressive spectacles that nature produces. They take place only rarely, and abruptly. The earliest texts of Hellenistic astrology (c. 150120 BCE) interpret eclipses as causes of the fates of kings and countries. ${ }^{16}$ Since Romulus was - from a Roman point of view - a king with a profound impact on world history, the alleged total solar eclipse of 772 BCE was a worthy starting point for his life.

In a second step, Tarutius added $273^{1 / 3}$ days, the standard length of human pregnancy in ancient astrological theory. ${ }^{17}$ This figure, which Varro quoted in De hebdomadibus, ${ }^{18}$ equals ten sidereal months of $27^{1 / 3}$ days each. The cuneiform tablet BM 33667 preserves the earliest known individual horoscope comparable to Tarutius' calculation for Romulus. ${ }^{19}$ It records the birth of an individual and his or her conception 273 days earlier. The author of this cuneiform text had started from the given day

\footnotetext{
${ }^{15}$ Grafton-Swerdlow, 'Horoscope', p. 149.

${ }^{16}$ Nechepsonis et Petosiridis fragmenta magica, ed. E. Riess, Philologus (18911893), suppl. 6, pp. 325-394, esp. fragments 6-8.

${ }^{17}$ See Katrin Frommhold, Bedeutung und Berechnung der Empfängnis in der Astrologie der Antike (Orbis antiquus, vol. 38, Münster, 2004), pp. 226-239.

${ }^{18}$ Varro hebd. 1 ap. Gell. 3.10.8.

19 See Francesca Rochberg, Babylonian Horoscopes (Transactions of the American Philosophical Society, vol. 88/1, Philadelphia, 1998), pp. 72-75, no. 7.
}

Culture and Cosmos 
of birth and calculated backwards to the astrologically significant date of conception. Tarutius worked the other way round, from conception to birth, obtaining 24 March 771 BCE, circa 18 years before the Parilia of 753 BCE. So Romulus, whose life had begun in the dark of the maternal womb at a solar eclipse, entered the light of the world at sunrise. In other words, the transition from dark to light in the life of Romulus corresponds to an analogous transition in the surrounding cosmos.

At this point Tarutius could have stopped, because he had answered Varro's question. Instead, he went on to examine the foundation of Rome, and a surprising thing happened. Tarutius must have felt disappointed by the planetary alignment on and around 21 April 753 BCE. Therefore he boldly pretended that the city had been founded seven months earlier on 9 Pharmouthi which is - in the Julian calendar - 4 October 754 BCE. This calendrical date is confirmed by the astronomical positions given unanimously by Solinus and John Lydus. For centuries before and after that date there is no other match for the transmitted data.

Solinus says (Solin. 1.18 , c. $300 \mathrm{CE}$ ) ${ }^{20}$

Qui [sc. Romulus] auspicato murorum fundamenta iecit duodeviginti natus annos, XI k. Mai., hora post secundam ante tertiam [plenam], sicut L. Tarruntius prodidit mathematicorum nobilissimus, Iove in piscibus, Saturno Venere Marte Mercurio in scorpione, Sole in tauro, Luna in libra constitutis.

Romulus made the auspices and set the foundations of Rome at the age of 18 , on the eleventh day before the calends of May [i.e. the $21^{\text {st }}$ of April], between the second and third hours, as Lucius Tarruntius the highly regarded mathematician declared, with Jupiter in Pisces, Saturn Venus Mars Mercury in Scorpius, the Sun in Taurus, and the Moon in Libra.

And John Lydus reports (Lyd. mens. 1.14, c. 550 CE): ${ }^{21}$

20 C. Iulii Solini Collectanea rerum memorabilium, 2nd ed. by Theodor Mommsen (Berlin, 1895).

21 Ioannis Laurentii Lydi Liber de mensibus, ed. Richard Wünsch (Leipzig, 1898). I follow the so-called Planudean recension of this passage; the Barberini recension offers nonsensical data.

Culture and Cosmos 


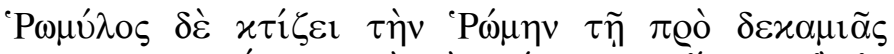

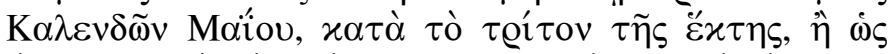

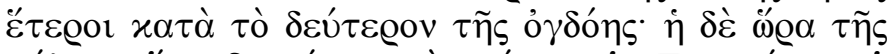
$\pi$

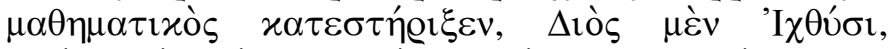

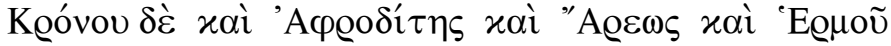

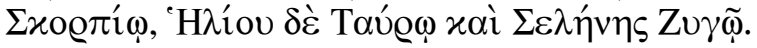

Romulus founds Rome on the $11^{\text {th }}$ day before the Calends of May in the third year of the sixth Olympiad [Ol. $6.3=754 / 3 B C E]$, or, as others have it, in the second year of the eighth Olympiad [Ol. $8.2=747 / 6 \mathrm{BCE}]$. The hour of the city was the second a bit before the beginning of the third, as Tarrutius the astrologer determined, with Jupiter in Pisces, Saturn and Venus and Mars and Mercury in Scorpius, the Sun in Taurus, and the Moon in Libra.

Figure 2. Foundation of Rome according to Tarutius (4 Oct. 754 BCE)

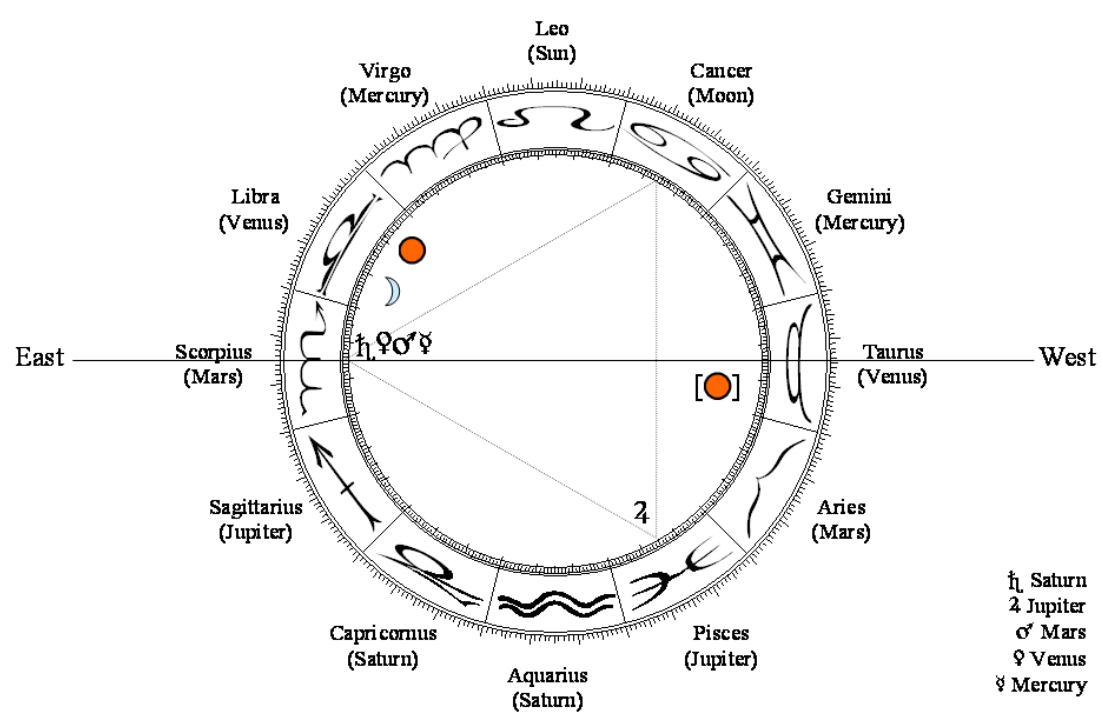

From their identical data it is clear that Solinus and Lydus both drew on an intermediary source $\boldsymbol{x}$ (see Figure 3). It seems that Varro reported all 
the calendrical and astronomical data given by Tarutius in full. The later authors used the available information in a selective manner: Plutarch quoted from Varro, ${ }^{22}$ omitting the astronomical data, while the author of $\boldsymbol{x}$ omitted the calendrical ones. The only two elements that both Plutarch and $x$ quote from Varro are the name Tar(r)utius and the time of day. The author of $\boldsymbol{x}$, who was primarily interested in the horoscope of Rome, not that of Romulus, must have committed a serious mistake. He must have found in Varro that not only the Moon, but also the Sun was in Libra, which is true for the date given by Plutarch. Probably the Egyptian calendrical data did not mean anything to the author of $\boldsymbol{x}$, but he knew that the solar position in Libra meant a date in October. Since he was sticking to the date in April, as both Solinus and Lydus show, $\boldsymbol{x}$ corrected the position of the Sun from Libra to Taurus in order to make it fit the Parilia in April. ${ }^{23}$ This is a clumsy attempt at correcting the data because it is part of basic astronomical knowledge that Mercury and Venus can never be more distant than one (Mercury) or two (Venus) signs from the Sun. It is unthinkable that an astronomer like Tarutius, who successfully reconstructed a planetary alignment that took place seven centuries before his own time, could have committed such a serious mistake. He must have located the Sun in Libra.

\section{Figure 3. Transmission of the Data}

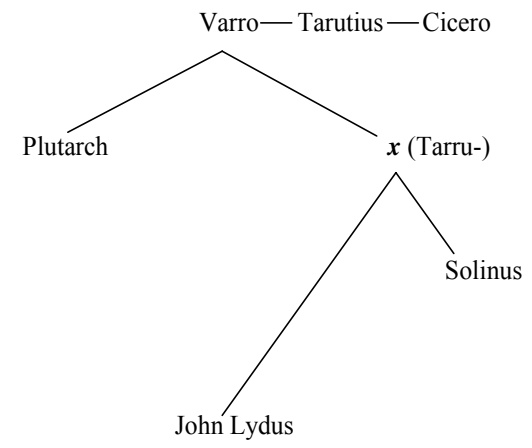

${ }^{22}$ See Hermann Peter, Die Quellen Plutarchs in den Biographieen [sic] der Römer (Halle, 1865, repr. Amsterdam, 1965), pp. 153-154 and 171.

${ }^{23}$ This is indicated in square brackets in Figure 2. I am following the interpretation of Grafton - Swerdlow, 'Chronology', p. 459. 
It is now time to ask why Tarutius moved the foundation of Rome from April 753 to the earlier date of October 754 BCE. ${ }^{24}$ The answer lies partly in Roman political theory and ideology, ${ }^{25}$ partly in the astrological doctrine of the houses (Gr. oĩxor, Lat. domus, domicilia). ${ }^{26}$ According to this doctrine which is, in its turn, based on the horoscope of the world (thema mundi), each of the five planets known to antiquity is given two signs of the zodiac, while the luminaries (Sun and Moon) are each assigned one of the two remaining signs. Whenever one of the seven planetary deities happens to be in its own house, it is supposed to rejoice and to have a particularly strong influence on earth.

The astrological effects of the planets are based on their physical qualities and on the character of the homonymous deities in Greek myth. The following interpretation is purposely concise. It could be substantiated with many references to ancient astrological handbooks, but it seems sufficient to adduce a few quotations exempli gratia. Note that all preserved astrological handbooks are at least half a century later than the time when Tarutius wrote his expertise for Varro. The loss of large parts of the Greek philosophical and scientific literature of the last three centuries BCE is well known. However, the basic agreement between all later astrological handbooks on the planetary effects that are at issue here strongly indicates that the same rules may quite safely be applied to the time of Tarutius.

In the horoscope of Rome as cast by Tarutius (Figure 2), Mars is in his own house, Scorpius. This is the one of his two houses that Mars allegedly occupied at the beginning of the world (thema mundi). Mars, the god of war, is the father of Romulus, and the city that Romulus founded is, according to Jupiter's famous prophecy in the Aeneid, a 'Mars-City' (Mavortia moenia). ${ }^{27}$ In this horoscope, Mars in his own house is tempered through the presence of Saturn, Venus, and Mercury. They add their own astrological qualities to the warlike character of

\footnotetext{
${ }^{24}$ I owe important observations to Pierre Brind'Amour, Le calendrier romain. Recherches chronologiques (Collection d'études anciennes de l'Université d'Ottawa, vol. 2, Ottawa, 1983), pp. 240-249, and to Abry, 'L'horoscope', pp. 131-134.

${ }^{25}$ This topic will be addressed later.

${ }^{26}$ See Auguste Bouché-Leclercq, L'astrologie grecque (Paris, 1899, repr. Brussels, 1963, Aalen, 1979), pp. 182-192.

${ }^{27}$ Verg. Aen. 1.276-277.
} 
Mars. The old, mythical grandfather of Mars, Saturn (Greek Kronos), cold and slow, moves far from the Sun in the most distant planetary sphere of the geocentric universe. When he and Mars come into conjunction, Saturn slows down the rushing energy of Mars and reduces his excessive heat to a sound measure. An early authority for this interpretation is Dorotheus of Sidon who summarized the traditional tenets of Hellenistic astrology in his versified manual in five books (c. 60 AD). A fragment from the third book has it that

when Saturn is in conjunction with Mars the Warlike, he makes the (otherwise angry) character gentle. For indeed the impetuous Mars, always vehement and swift, sets unreflecting and inconsiderate speed into rapid motion, because he is hot; Saturn, instead, is slow; but when both are mixed, the mortal (who is being born) will be midway between them and therefore the best. ${ }^{28}$

The same doctrine which is based on the opposition of physical qualities (hot/cold, fast/slow) can be found in later authors. ${ }^{29}$ In the case of Venus, instead, the astrological interpretation is based on Greek myth. Venus adds gentleness and moderation to the innate brutality and fury of Mars. This mythical motif is, of course, not limited to astrological manuals. It goes back to Homer, ${ }^{30}$ and only a few years before the time of Tarutius, Lucretius had given it a prominent treatment in the opening of De rerum natura where he beseeched Venus to soothe the god of war and thereby bestow peace on the Roman people. ${ }^{31}$ Mercury adds rationality and

${ }^{28}$ Doroth. Sid. pp. 368.25-369.3 Pingree (= frg. 58c Stegemann): $\eta^{2} \delta$ ò

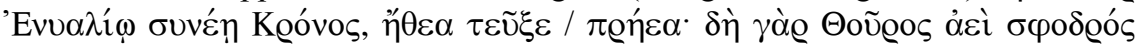

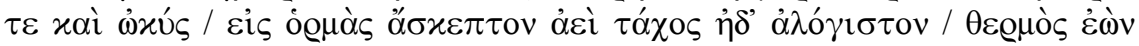

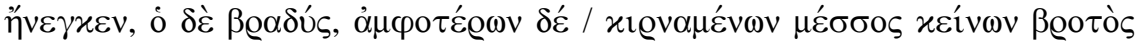

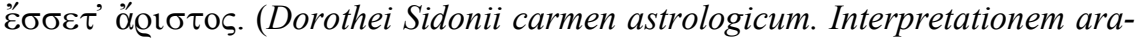
bicam in linguam anglicam versam una cum Dorothei fragmentis et graecis et latinis ed. D. Pingree, Leipzig, 1976).

${ }^{29}$ See, for instance, Firm. math. 6.22.4-5 and Maneth. (Astrol.) 5.58-61.

${ }^{30}$ Hom. Od. 8.266-369.

${ }^{31}$ Lucr. 1.31-40, esp. 38-40: 'hunc tu, diva, tuo recubantem corpore sancto / circum fusa super, suavis ex ore loquellas / funde petens placidam Romanis, incluta, pacem.'

Culture and Cosmos 
learning to the impetuous strength of Mars. Jupiter is not only the beneficent astrological deity par excellence but plays an important role as saviour of the city in the legendary origins of Rome. According to Livy, Romulus invoked the assistance of Jupiter Stator when his army was about to yield to the attack of the Sabine warriors; Jupiter heard the prayer and gave the Romans the strength to withstand. ${ }^{32}$ In this horoscope, Jupiter is in his own house, Pisces, and casts a propitious trine aspect to Mars and his group in Scorpius. Among the various geometrical figures that can be inscribed within a circle, the triangle is, due to Pythagorean number symbolism, positive, while the square is negative. Note that Mars and his group are on the Eastern horizon, one of the strongest positions possible in a horoscope.

Now to the luminaries. Grafton and Swerdlow offer a speculation about the choice of 4 October 754 BCE: according to modern computation the Sun was very near the autumnal equinox on that day, and 'Tarutius could even have thought it was the equinox'. ${ }^{33}$ However, they do not take into account the fact that all practising astrologers until at least 200 years after Tarutius used sidereal, not tropical longitudes. We should therefore add some $16^{\circ}$ to all tropical longitudes obtained by modern computation. ${ }^{34}$ That leads to a solar position of $19^{\circ}$ (not $3^{\circ}$ ) Libra. It looks like Tarutius' first priority was not to find the equinox date but the first following day on which both Sun and Moon are in Libra. One may object that on 4 October $754 \mathrm{BCE}$ this is no longer the case for the Moon because its tropical position by then is c. $12^{\circ}$ Scorpius. As a reply, I can but offer - with due caution - the following explanation: For

\footnotetext{
${ }^{32}$ Liv. 1.12.3-10. See further Ov. fast. 4.827-828 where Romulus, in the act of founding Rome, invokes Jupiter and his father Mars (and his mother Vesta, who has no astrological equivalent).

${ }^{33}$ See Grafton - Swerdlow, 'Chronology', p. 459.

${ }^{34}$ At the beginning of the era of Augustus (30 BCE) the sidereal longitudes were some $6^{\circ} 15^{\prime}$ higher than the tropical longitudes. Another $10^{\circ}$ must be added for the precession rate over a time span of some 720 years. For details, see Astronomical Papyri from Oxyrhynchus (P. Oxy. 4133-4300a), ed. with Translations and Commentaries by Alexander Jones (Memoirs of the American Philosophical Society, vol. 233, Philadelphia, 1999), i, p. 343. Although the astronomical discussion of Grafton and Swerdlow is based on tropical longitudes, its overall result (that Tarutius really meant Oct. 4, 754 BCE) remains equally valid when using sidereal longitudes. In the latter case, the overall inaccuracies are even smaller.
} 
astrological reasons it is important that the Moon be waxing, not waning, at the beginning of a building project. ${ }^{35}$ In other words, if the Sun is at $19^{\circ}$ Libra, the Moon should stand within the last eleven degrees of that sign. There is the further astrological requirement that the time of day fall into the first few hours after sunrise, so that Scorpius be ascending. If so, Tarutius missed the only satisfactory date (Oct. 3) by one day. This seems easily possible with regard to the quick daily motion of the Moon, ${ }^{36}$ and Tarutius' mistake would be smaller than assuming a three day error in computing the equinox date of the slowly moving Sun. ${ }^{37}$

The apparently intentional allocation of both luminaries in Libra offers more than one advantage. From an ancient astrological point of view, Libra is not only a symbol of cosmic balance and harmony, but of justice, too. ${ }^{38}$ In this horoscope, the sign of Libra is emphasized by the presence of the two biggest and mightiest celestial bodies, which astrologers used

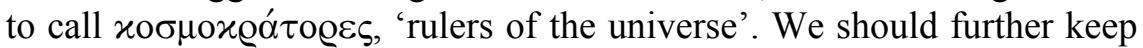
in mind Cicero's words that Tarutius predicted the destiny of the city (nec eius fata canere dubitabat). ${ }^{39}$ This means that Tarutius made the most important single prediction that ancient clients expected from their astrologers, namely that about the length of life. We do not know which method Tarutius applied, but such predictions were mostly based on the rising times of the zodiacal signs. They are longest around $0^{\circ}$ Libra and shortest around $0^{\circ}$ Aries. Therefore it is probable that Tarutius interpreted the alignment of 4 October $754 \mathrm{BCE}$ as indicating a very long lifetime of

35 See, for instance, Doroth. Sid. pp. 386.19-387.2 Pingree (= Heph. Theb. 3.7.10).

${ }^{36}$ The average value is, according to ancient sources, $13 \%$ day.

${ }^{37}$ Besides this, Tarutius must have known that Mercury cannot be in Scorpius at the time of the autumnal equinox when the Sun is at the very beginning of the preceding sign. See Otto Neugebauer, A History of Ancient Mathematical Astronomy (Berlin et al., 1975), pp. 804-805, on the maximum elongation of Mercury which is $22^{\circ}$ according to most ancient sources (a few texts speak of $25^{\circ}$ or even $28^{\circ}$, but that is still less than an entire sign).

${ }^{38}$ See Wolfgang Hübner, Die Eigenschaften der Tierkreiszeichen in der Antike. Ihre Darstellung und Verwendung unter besonderer Berücksichtigung des Manilius (Sudhoffs Archiv. Beihefte, vol. 22, Wiesbaden, 1982) [hereafter Hübner, Eigenschaften], pp. 222-223 (ch. 4.62).

${ }^{39}$ For the full quotation, see pp. 45-46 above. 
the city of Rome. We know that Varro was interested in such predictions. In book 18 of his Antiquitates he quoted a learned augur called Vettius who had interpreted the 12 vultures that appeared to Romulus before he founded the city as a heavenly sign that the city would have a life span of 1200 years. $^{40}$

Altogether there is a high probability that Tarutius interpreted the alignment of 4 October $754 \mathrm{BCE}$ as indicating the fate of Rome to permanently rule the world through the judicious employment of strong armies, and thereby to bring peace and justice to mankind. Such an astrological interpretation makes perfect sense in the Roman intellectual environment of those very years around $45 \mathrm{BCE}$ when topics like just dominion and just war assumed a greater importance than ever before. Suffice it to mention the philosophical and political works of Cicero (he was a personal acquaintance of Tarutius ${ }^{41}$ ), especially the treatise De re publica which had been published in 51 BCE: the whole third book was devoted to the topic of justice, and Cicero had given his work De re publica a cosmic scope, not only through the initial discussion of the double sun (1.15sqq.) and the final Somnium Scipionis but also through the central idea (expressed by Laelius) that it is only through extending the law of the universe (in other words, the divine and eternal principle of right reason) to the behaviour of states that those states can be preserved and prosper. There is further literary, numismatic and other evidence showing that around the middle of the first century BCE the Platonic cardinal virtue of justice was becoming a key notion of political theory and propaganda in Rome. ${ }^{42}$ It seems plausible that Tarutius was inspired by the importance of this topic in contemporary debates among Roman intellectuals and that he replaced the traditional foundation date on the pastoral feast of the Parilia, which is based on nothing else than the legendary pastoral life of Romulus and Remus, with a new date that was capable of conveying a deeper philosophical and patriotic sense.

But let us also examine the planetary alignment of that traditional date in April, seven months after the date chosen by Tarutius. Table 1 gives both the tropical and sidereal longitudes, but from the above discussion it

\footnotetext{
${ }^{40}$ Varro ant. rer. hum. 18 frg. 4 Mirsch (= frg. 2 Popma) ap. Cens. 17.15.

${ }^{41}$ Cic. div. 2.98 familiaris noster (see p. 45 above).

${ }^{42}$ See the important remarks of Abry, 'L'horoscope', p. 134.
} 
is clear that our preference is for the sidereal ones. ${ }^{43}$ The anachronistic choice of tropical longitudes would lead to a chart slightly different from Figure 4 (below), the most important difference regarding the position of Mars. In order to draw a chart, we choose sunrise as the time of day. ${ }^{44} \mathrm{We}$ shall, however, abstain from interpreting the positions of the signs and planets with regard to the horizon.

Table 1. Planetary longitudes on 21 April 753 BCE, 5:30 AM

$$
\begin{gathered}
\text { (Rome) } \\
\left(\mathrm{R}_{\mathrm{X}}=\right.\text { Retrograde) }
\end{gathered}
$$

\begin{tabular}{|c|c|c|}
\hline & Tropical & Sidereal \\
\hline Sun & $22^{\circ} 46^{\prime} \gamma$ & $9^{\circ} \mathrm{\gamma}$ \\
\hline Moon & $11^{\circ} 21^{\prime} m$ & $27^{\circ} m$ \\
\hline Saturn & $15^{\circ} 30^{\prime} m\left(\mathrm{R}_{\mathrm{x}}\right)$ & $2^{\circ} x^{\top}\left(\mathrm{R}_{\mathrm{x}}\right)$ \\
\hline Jupiter & $10^{\circ} 54^{\prime} \gamma$ & $27^{\circ} \gamma$ \\
\hline Mars & $\left.20^{\circ} 22^{\prime}\right)($ & $6^{\circ} \gamma$ \\
\hline Venus & $\left.29^{\circ} 49^{\prime}\right)\left(\mathrm{R}_{\mathrm{x}}\right)$ & $16^{\circ} \Upsilon\left(R_{x}\right)$ \\
\hline Mercury & $4^{\circ} 59^{\prime} \gamma$ & $21^{\circ} \gamma$ \\
\hline
\end{tabular}

\footnotetext{
${ }^{43}$ They are here computed by adding some 16 degrees (see above, n. 34 ) to the tropical data. In the results, fractions of degrees are omitted because we can but approximately restore the sidereal longitudes used by Tarutius. Note also that the attempt of $\boldsymbol{x}$ (see above, Figure 3) at correcting the solar position from Libra to Taurus is based on sidereal longitudes. The tropical solar longitude at the time of Tarutius is c. $28^{\circ} \gamma$, and still at the time of Plutarch it is in the last degree of Aries.

${ }^{44}$ Compare the foundation time in the October horoscope (Plut. Rom. 12.6, quoted above).
}

Culture and Cosmos 
Figure 4. 21 April 753 BCE, 5:30 AM (Rome) (sidereal longitudes)

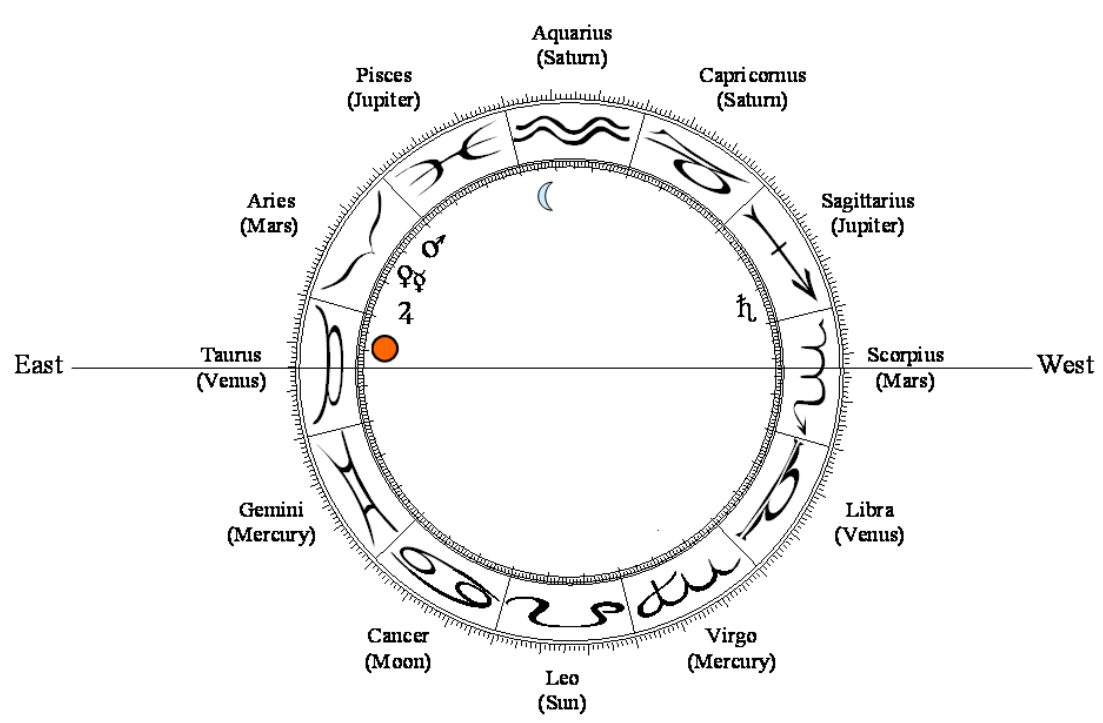

Astrologically speaking, this chart is weaker than the one chosen by Tarutius. At best, one planet happens to enjoy an astrological dignity: Mars is in Aries, one of his own houses. In this case similar soothing effects on him, as discussed earlier in the case of 4 October 754 BCE, can be pointed out. But since the longitude of Mars is notoriously difficult to determine, we cannot exclude the possibility that Tarutius thought Mars was still in Pisces, where his tropical longitude falls. Two planets Venus and Saturn - are retrograde. No planet displays its energy in Libra. The Moon, whose position in Libra Cicero, Solinus and Lydus had quoted from Tarutius as particularly important, is in Aquarius on 21 April $753 \mathrm{BCE}$, far from Libra; even worse, it is waning (building projects, as we have said, should start when the Moon is waxing). ${ }^{45}$ Most of the planets are located near the spring equinox, where zodiacal rising times and therefore life expectancies are the shortest. And - unlike the October chart - there is no relation to astrological geography and its political

\footnotetext{
${ }^{45}$ See above, n. 35.
} 
significance. ${ }^{46}$ Only one point speaks in favour of the Parilia alignment, namely that most of the planets stand in Aries and Taurus, the two signs that are astrologically associated with shepherds and farmers. ${ }^{47}$ However, the whole symbolism of balance and justice is missing, and it is hard to bring the positions of Moon and Saturn into a consistent overall interpretation with the other planets.

If one analyses the whole year preceding April 753, which is the eighteenth year of Romulus' life, one finds that the alignment chosen by Tarutius and dated to 4 October $754 \mathrm{BCE}$ is the most attractive for explaining in astrological terms the lasting military power of Rome and its just dominion of the world.

It is reasonable to assume that Tarutius explained the astrological advantages of the date in October to Varro, but that Varro preferred to stick to the traditional date of the foundation in April. That Varro did not change his mind is clear from a passage in De re rustica $(37 \mathrm{BCE}) .{ }^{48}$ On the other hand, Varro had been a student of Academic philosophy, and he knew that in more than one respect he reported opinions, not certain knowledge. Therefore he often quotes other scholars' opinions even if he disagrees with them. It may be due to this attitude that Varro apparently quoted all the calendrical and astronomical data provided by Tarutius in detail in one of his lost antiquarian works. In all likelihood this work was De gente populi Romani of $43 \mathrm{BCE}$ in which Varro discussed the prehistory of Rome from the Ogygian flood to the beginning of the period of the Roman kings.

A comparison with three Roman poets will now round off the interpretation. Only a few years after Varro's consultation of Tarutius, Vergil recommends in the proem of the Georgics (composed c. 39-29

\footnotetext{
${ }^{46}$ See the important remarks of Abry, 'L'horoscope', p. 133.

${ }^{47}$ See Manil. 4.124-151 (Aries - Taurus) and 5.115-117 about the Ram's paranatellon Haedi. See also the commentary to these passages by Hübner, Eigenschaften, pp. 526-543.

${ }^{48}$ Varro asks in a rhetorical fashion (Varro rust. 2.1.9): 'Romanorum vero populum a pastoribus esse ortum quis non dicit? Quis Faustulum nescit pastorem fuisse nutricium qui Romulum et Remum educavit? Non ipsos quoque fuisse pastores obtinebit quod Parilibus potissimum condidere urbem?' ('But who denies that the Roman people originated from shepherds? Who does not know that Faustulus, the foster-father of Romulus and Remus, was a pastor? And that they themselves also were shepherds, who will not admit that since they founded the city on the very day of the Parilia?')
} 
BCE) that Augustus take a heavenly seat in that part of the zodiac where the oversized scorpion, which traditionally occupied the space of two signs, is already respectfully withdrawing its claws. ${ }^{49}$ Vergil means Libra, the sign of cosmic balance under which Augustus had actually been born on 23 September 63 BCE. We cannot say if Vergil also knew and was thinking of the foundation horoscope of Tarutius. However, the astrological symbolism of that horoscope would well suit Vergil's panegyric appeal to Augustus. ${ }^{50}$ Besides, Vergil was - generally speaking - familiar with Varro's works. The very proem of the Georgics quoted above contains a literary allusion to the twelve Di consentes in the opening of Varro's De re rustica. ${ }^{51}$

Manilius has a passage that modern commentators rightly take as a reference to the foundation horoscope of Tarutius. In his chapter on zodiacal geography (Manil. 4.744-817), he asks: 'What sign would better have the care of Italy, if Italy could choose, than that which controls all, knows the weights of things, marks totals, and separates the unequal from the equal, the sign in which the seasons are balanced and the hours of night and day match each other? Italy belongs to the Balance, her rightful sign: beneath it Rome and her sovereignty of the world were founded, Rome, which controls the issue of events, exalting and depressing nations placed in the scales: beneath this sign was born the emperor, who has now effected a better foundation of the city and governs a world which hangs on his command alone. ${ }^{52}$ We shall return to this passage shortly.

\footnotetext{
${ }^{49}$ Verg. georg. 1.33-35: 'qua locus Erigonen inter Chelasque sequentis / panditur (ipse tibi iam bracchia contrahit ardens / Scorpios et caeli iusta plus parte reliquit).'

${ }^{50}$ See Wolfgang Hübner, 'Das Sternbild der Waage bei den römischen Dichtern', Antike und Abendland (1977), vol. 23, pp. 50-63, esp. p. 55.

${ }^{51}$ See Thomas Baier, Werk und Wirkung Varros im Spiegel seiner Zeitgenossen. Von Cicero bis Ovid (Hermes Einzelschriften, vol. 73, Stuttgart, 1997), pp. 147149 and 188, who further argues that the entire second half of the Georgics has been inspired by Varro's De re rustica.
}

${ }^{52}$ Manil. 4.769-777: 'quod potius colat Italiam, si seligat, astrum / quam quod cuncta regit, quod rerum pondera novit, / designat summas et iniquum separat aequo, / tempora quo pendent, coeunt quo noxque diesque? / Hesperiam sua Libra tenet, qua condita Roma / orbis et imperium retinet discrimina rerum, / lancibus et positas gentes tollitque premitque, / qua genitus Caesar melius nunc condidit urbem / et propriis frenat pendentem nutibus orbem.' (Manilius,

Culture and Cosmos 
64 Ancient Scholars on the Horoscope of Rome

Some new observations can be made with regard to Lucan's poem on the civil war. In the first book, at Julius Caesar's crossing of the Rubicon, the people of Rome are seized with panic. Dire omens occur, and Nigidius Figulus, that Roman expert in all sorts of magic and astral sciences who is said to have interpreted the birth of Octavian Augustus as that of a world ruler, ${ }^{53}$ delivers a terrifying astrological prognostication. ${ }^{54}$ His speech is bracketed by two others, that of the Etruscan priest Arruns and the vision of a Roman lady driven to prophetical frenzy by Phoebus Apollo. ${ }^{55}$ While Arruns represents the traditional Etruscan art of extispicy, the Roman matrona combines the Greek cult of Dionysus with Apollinian oracular art. The inclusion of Nigidius' speech between the other two not only allows Lucan to pay tribute to the comparatively recent and fashionable art of astrology, but also to give the calamity of Rome a cosmic dimension. Nigidius emphasizes this latter feature by foretelling that the end of Rome and of mankind is imminent. ${ }^{56} \mathrm{He}$ then makes a threefold distinction, based on the same doctrine of the houses that underlies Tarutius' horoscope of Rome. In each of the three cases Nigidius seems to envisage the decisive planet not only in his own house but in the upper culmination, too. The first two scenarios, Saturn in Aquarius and the Sun in Leo, would lead to a deluge or a general conflagration respectively, that is: to Stoic kataklusmos or ekpurōsis. ${ }^{57}$ But neither of these two possibilities of total destruction of the world applies here. Instead, Mars in Scorpius is bringing about doomsday by war. The following description of the positions of the stars and planets is fictitious and cannot be dated by means of astronomy. Recent scholarship has overcome Housman's unjust criticism of Lucan and revived Kepler's

Astronomica, ed. and trans. by G.P. Goold, Cambridge/Mass. - London 1997 $\left.\left[{ }^{1} 1977\right]\right)$.

${ }^{53}$ Suet. Aug. 94.5.

${ }^{54}$ Lucan. 1.639-672.

${ }^{55}$ Lucan. 1.584-638 and 1.673-695.

${ }^{56}$ Lucan. 1.644-645: urbi generique paratur / humano matura lues.

${ }^{57}$ Lucan. 1.651-657.

Culture and Cosmos 
interpretation of this text as a fictitious, poetic horoscope. ${ }^{58}$ It has also been noted correctly that the speech of Nigidius contains intertextual allusions to Vergil, both to the opening of the Georgics (see above) and to the prophecy of Jupiter in the first book of the Aeneid. ${ }^{59}$ But it has been overlooked so far that this speech might contain another intertextual allusion: It is very possible that Lucan, in describing the recent 'disaster' of Rome, is purposely perverting the foundation horoscope of the city as cast by Tarutius.

My arguments are as follows: Instead of assigning clear positions to the planets, Nigidius says that all of them - with the exception of Mars are somewhere below the horizon, powerless and paralysed. Mars dwells - as in Tarutius' horoscope of Rome - in Scorpius, his own house (Figure 5). But the situation has changed profoundly: at the origin of Rome Mars was rising in Scorpius, together with three other planets and with a beneficent aspect of Jupiter. Seven centuries later, the Roman god of war has reached the zenith ${ }^{60}$ of the cosmos, but he is there alone. ${ }^{61}$ The two preceding lines say explicitly that Venus, Jupiter and Mercury are absent and weak. ${ }^{62}$ In other words, all the beneficent planets have lost their influence on Mars. As a consequence, his unrestrained energy becomes destructive: Mars sets on fire the sign of Scorpius, and his heat is so excessive that he totally burns even the neighbouring Claws, that is: Libra. ${ }^{63}$ The 'cosmocrators', the Sun and Moon, are no longer in Libra, as at the foundation of Rome, but somewhere below the horizon, powerless. While in Tarutius' alignment the energy of Mars had been soothed and tempered in any imaginable way, so as to work with justice for the best of

\footnotetext{
${ }^{58}$ See Francisco Barrenechea, 'The Star Signs at Brundisium: Astral Symbolism in Lucan 2.691-2’, Classical Quarterly n.s. (2004), vol. 54, pp. 312-317, esp. pp. 314-315.

${ }^{59}$ See M. Annaei Lucani Belli Civilis Liber primus, Testo critico, introduzione e commento a cura di Donato Gagliardi (Speculum, vol. 10, Naples, 1989), p. 121, ad Lucan. 1.667-669.

${ }^{60}$ Astronomically more accurate: the upper culmination.

${ }^{61}$ Lucan. 1.663: et caelum Mars solus habet.

${ }^{62}$ Lucan. 1.660-662: nam mitis in alto / Iuppiter occasu premitur, Venerisque salubre / sidus hebet, motuque celer Cyllenius haeret.

${ }^{63}$ Lucan. 1.658-660: tu, qui flagrante minacem / Scorpion incendis cauda chelasque peruris, / quid tantum, Gradive, paras?
}

Culture and Cosmos 
66 Ancient Scholars on the Horoscope of Rome

Rome and the world, it is now turned into fury and madness (furor and rabies) ${ }^{64}$

Figure. 5. Outbreak of the Civil War

(Lucan. 1.639-672)

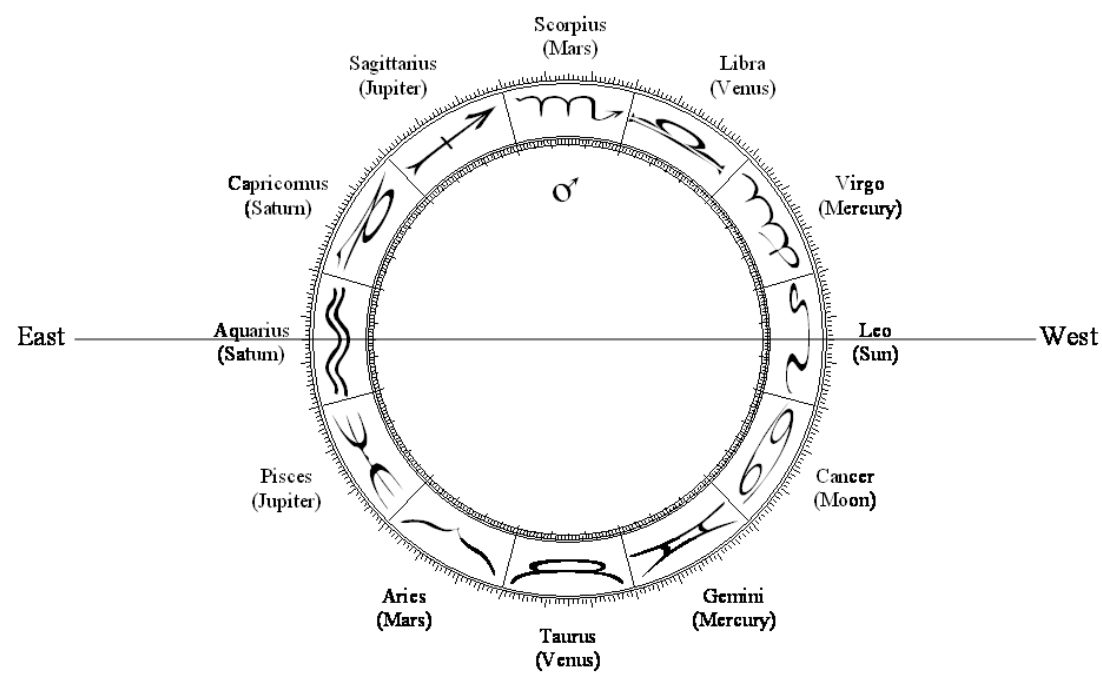

And as if the uncontrolled raging of Mars were not enough, Lucan brings, so to speak, a second Mars on the heavenly stage, the wild giant Orion whose sword glitters terribly. ${ }^{65}$ According to myth, Orion was killed by a scorpion sent by Artemis, and therefore he is always at the opposite end of the skies with respect to Scorpius, fleeing from the deadly sting. In reality, the two opposite constellations are never visible at the same time, but Lucan purposely suspends the laws of nature in order to create a gloomy picture of two warlike cosmic powers, hostile to each other and left alone on stage, like the two opposite parties of the civil war.

Ancient poetry is rich in intertextual allusions, but it is part of the poetical technique to omit explicit references to the respective sources.

\footnotetext{
${ }^{64}$ Lucan. 1.666 and 1.669.

${ }^{65}$ Lucan. 1.665 ensiferi nimium fulget latus Orionis.
} 
Therefore in this case, too, it is impossible to adduce definitive proof that Lucan knew the foundation horoscope of Tarutius and that he perverted it intentionally. But the perversion of traditional Roman values and literary models into their opposites is typical of Lucan, ${ }^{66}$ and the astrological speech of Nigidius gains in terms of depth and desperation when read against that noble picture of Rome that had been proposed, with the same astrological means, a century earlier by Tarutius of Firmum. ${ }^{67}$

Since Lucan knew the poem of Manilius, ${ }^{68}$ there may well be a further intertextual reference in the speech of Nigidius, namely to the above quoted lines Manil. 4.769-777. If this is the case, we have two purposely different ways of alluding to Tarutius. While Manilius flatters Tiberius by praising this Emperor's reign as a second and better foundation of Rome under similar astrological circumstances as in Tarutius' foundation horoscope ${ }^{69}$ Lucan exploits the remaining option of comparing the first and only foundation of Rome to a mad act of destruction, again based on similar though significantly modified astrological circumstances. In other words, there seem to be two diametrically opposed modifications of the common model, one to the better, by the supporter of the Julio-Claudian dynasty which emerged from the civil war, and one to the worse, by their critic.

In conclusion, the following points deserve to be emphasized. As part of his investigation of the early history of Rome, Varro was interested in the birthday of Romulus. He hoped to determine this date to the very day and hour with the help of an expert in astral sciences. Tarutius not only calculated the requested birthdate but also proposed a correction of the

${ }^{66}$ See Christine Schmitz, "Umwertung aller Werte" in Lucans Pharsalia', Gymnasium (2007), vol. 114, pp. 233-249.

${ }^{67}$ Maybe a further element of perversion is present here with regard to the traditional gods that had in earlier poems presided over epic action and made sure that the just order of the universe be ultimately preserved. On the whole, Lucan excludes them from his poem, but here he may be seen as re-introducing the gods - at least the destructive ones - through the astrological planetary deities.

${ }^{68}$ See Ferdinand Schwemmler, De Lucano Manilii imitatore (Giessen, 1916), esp. pp. 15, 27-28, and 30 where various imitations of Manilius within the speech of Nigidius are discussed.

${ }^{69}$ See Manil. 4.776 Caesar melius nunc condidit urbem (the full quotation is in n. 52 above). 
68 Ancient Scholars on the Horoscope of Rome

traditional foundation date of the city. It seems that Tarutius was inspired by the recent debate about political theory in the capital of the Roman Empire, and especially by its emphasis on justice. Both dates of the foundation of Rome, the traditional one as well as that proposed by Tarutius, lack historical truth. We know that Rome was not founded on this or that day, but that the city grew out of several clusters of iron age huts $\left(9^{\text {th }} / 8^{\text {th }} \mathrm{c}\right.$. BCE) scattered over the hills. The traditional date of the foundation on 21 April is a later invention; it is first attested in literature and epigraphy during the lifetime of Varro. While this date in April sticks to the legendary past and is based on the somewhat naïve assumption that the shepherds Romulus and Remus can hardly have founded their city on another day than the pastoral feast of the Parilia ${ }^{70}$ Tarutius's new date conveys a more philosophical meaning and a thoroughly updated selfimage of Rome. Its weak point - and this Varro, a notoriously pragmatic scholar, ${ }^{71}$ must have realized - lies in the fact that it is fascinating only for a small group of learned intellectuals, preferably followers of Stoicism and astrology. There was no chance of modifying, in such a way, the firmly established calendar of the Roman festivals as celebrated each year by the Roman people. Nevertheless the preservation of the ancient reports on this unusual research project deepens our knowledge of the interests, methods, and scientific competences of ancient scholars like Varro and Tarutius.

\footnotetext{
${ }^{70}$ See, for instance, Varro rust. 2.1.9 (note 48 above). There is, however, more to be said about the traditional connection of the foundation of Rome with the Parilia: see Jens Henrik Vanggaard, 'On Parilia', Temenos (1971), vol. 7, pp. 90-103, esp. pp. 101-103; Mary Beard, 'A Complex of Times: No More Sheep on Romulus' Birthday', Proceedings of the Cambridge Philological Society (1987), vol. 213, pp. 1-15; Fritz Graf, 'Römische Aitia und ihre Riten. Das Beispiel von Saturnalia und Parilia', Museum Helveticum (1992), vol. 49, pp. 1325 , esp. pp. $22-25$.

${ }^{71}$ See Burkhart Cardauns, Marcus Terentius Varro. Einführung in sein Werk (Heidelberg, 2001), p. 20 ('der Pragmatiker'); p. 53 ('der pragmatische Gelehrte'); p. 57 ('sehr nüchtern').
} 